\title{
The variability in the relationship between black carbon and carbon monoxide over the eastern coast of China: BC aging during transport
}

\author{
Qingfeng Guo ${ }^{1, a}$, Min $\mathrm{Hu}^{1,2}$, Song Guo ${ }^{1}$, Zhijun Wu ${ }^{1}$, Jianfei Peng ${ }^{1}$, and Yusheng Wu \\ ${ }^{1}$ State Key Joint Laboratory of Environmental Simulation and Pollution Control, College of Environmental \\ Sciences and Engineering, Peking University, Beijing, China \\ ${ }^{2}$ Beijing Innovation Center for Engineering Science and Advanced Technology, Peking University, Beijing, China \\ anow at: Beijing SDL Technology Co., Ltd., Beijing, China \\ ${ }^{b}$ now at: Department of Physics, University of Helsinki, Helsinki, Finland
}

Correspondence to: $\mathrm{Min} \mathrm{Hu}$ (minhu@pku.edu.cn)

Received: 22 January 2017 - Discussion started: 21 March 2017

Revised: 23 July 2017 - Accepted: 1 August 2017 - Published: 6 September 2017

\begin{abstract}
East Asia is a densely populated region with a myriad of primary emissions of pollutants such as black carbon (BC) and carbon monoxide (CO). To characterize primary emissions over the eastern coast of China, a series of field campaigns were conducted in 2011, including measurements from a ship cruise, island, and coastal receptor sites. The relationship between $\mathrm{BC}$ and $\mathrm{CO}$ is presented here for the first ship cruise (C1), the second ship cruise (C2), an island site (Changdao Island, CD), and a coastal site (Wenling, WL). The average BC mass concentrations were 2.43, 2.73, 1.09, 0.94, and $0.77 \mu \mathrm{g} \mathrm{m}^{-3}$ for CD, WL, C1-YS (Yellow Sea), C1-ES (East China Sea), and C2-ES, respectively. For those locations, the average $\mathrm{CO}$ mixing ratios were 0.55 , $0.48,0.31,0.36$, and $0.27 \mathrm{ppm}$. The high loadings of both $\mathrm{BC}$ and $\mathrm{CO}$ imply severe anthropogenic pollution over the eastern coast of China. Additionally, the linear correlation between $\mathrm{BC}$ and $\mathrm{CO}$ was regressed for each location. The slopes, i.e., the ratios of $\triangle \mathrm{BC}$ to $\triangle \mathrm{CO}$ derived from their relationship, correlated well with the ratios of diesel consumption to gasoline consumption in each province/city, which reveals vehicular emission to be the common source for $\mathrm{BC}$ and $\mathrm{CO}$ and that there are distinct fuel structures between North and South China. The $\Delta \mathrm{BC} / \Delta \mathrm{CO}$ values at coastal sites (Changdao Island and Wenling) were much higher than those over the Yellow Sea and East China Sea, and the correlation coefficients also showed a decreasing trend from the coast to the sea. Therefore, the quantity of $\triangle B C / \triangle C O$ and
\end{abstract}

the correlation coefficients are possible indicators for the aging and removal of $\mathrm{BC}$.

\section{Introduction}

Atmospheric radiative forcing is caused by a variety of particulate and gaseous air pollutants. Among the particulate matters, black carbon (BC) impacts the Earth's climate directly through the absorption of solar radiation and indirectly through its role as cloud condensation nuclei (Bond et al., 2013). The absorption induced by BC is markedly enhanced by the atmospheric oxidation and aging, as investigated by many chamber studies (Peng et al., 2016b; Guo et al., 2016; Schnaiter et al., 2005). BC aging includes physical condensation-coagulation and chemical oxidation, which transform BC from hydrophobic to hydrophilic particles (Huang et al., 2013). It not only plays an important role in global BC distribution and budget (He et al., 2016; Huang et al., 2013) but also has a significant influence on optical and hygroscopic properties of BC particles (Bond et al., 2006; He et al., 2015; Zhang et al., 2008; Khalizov et al., 2009a). These effects will potentially result in increasing extreme weather and weakening atmospheric circulations (Wang et al., 2013, 2016; Li et al., 2016). Among the gaseous pollutants, carbon monoxide (CO) is an indirect greenhouse gas through the production of ozone, methane, and carbon 
dioxide (Girach et al., 2014). Both BC and CO are products of incomplete combustion of carbon-based fuels (Wang et al., 2015). Though BC and CO are from similar sources, their emission ratios vary significantly for different sources, so the variations in measured ratios can indicate the presence of different sources (McMeeking et al., 2010; Bond et al., 2004). In addition, the source-specific emission ratio is an important constraint on global climate and regional air quality model (Spackman et al., 2008).

Sources of BC colocated with $\mathrm{CO}$ will result in their concentration correlations, since the variances in the concentrations are affected by the same atmospheric process (Wang et al., 2011). There have been a number of studies about the relationship between $\mathrm{BC}$ and $\mathrm{CO}$, and most of these show high correlations (e.g., Zhou et al., 2009; Spackman et al., 2008). They have generally been conducted at a stationary site or a cruise, while the simultaneous measurement of the both is rare. The slopes, i.e., the ratios of $\triangle \mathrm{BC}$ to $\triangle \mathrm{CO}$, from the linear regressions are used to indicate different emission sources (Girach et al., 2014; Lee et al., 2013; Pan et al., 2011) and validate BC emissions from bottom-up inventories (Wang et al., 2011; Han et al., 2009).

For BC, its atmospheric life cycle includes emissions, transport, aging, and removal (Bond et al., 2013). The relationship between $\mathrm{BC}$ and $\mathrm{CO}$ is the result of a balance between emission sources and sinks (Spackman et al., 2008; Wang et al., 2015). Thus, differences in emission sources and removal rates (i.e., sinks) are often used to explain differences in $\triangle \mathrm{BC} / \triangle \mathrm{CO}$ ratios (McMeeking et al., 2010). To a certain extent, the variability due to emissions and transport can be accounted for in $\triangle \mathrm{BC} / \triangle \mathrm{CO}$ values (De Gouw and Jimenez, 2009; de Gouw et al., 2005). The atmospheric lifetime of $\mathrm{BC}$ is shorter than $\mathrm{CO}$ owing to cloud and precipitation scavenging, which results in decreasing $\triangle B C / \triangle C O$ with increasing time and distance from source. Therefore, the variations in $\triangle \mathrm{BC} / \triangle \mathrm{CO}$ values also reflect air mass aging and wet removal processes in addition to sources (McMeeking et al., 2010).

The eastern coastal areas are the most developed in China and are in the transport pathway of the Asian pollution outflow, especially during the East Asian monsoon in winter. The air pollutants emitted from this region and its upwind regions not only result in the deterioration of the air quality on a regional scale but also exert an influence on downwind countries in the Pacific Rim (Feng et al., 2007; Peltier et al., 2008). In order to characterize the outflow of primary emission over the eastern coast of China, campaigns including two cruises and two coastal sites were conducted in 2011. Among these was a campaign from March to April including both the island station and marine cruise observations.

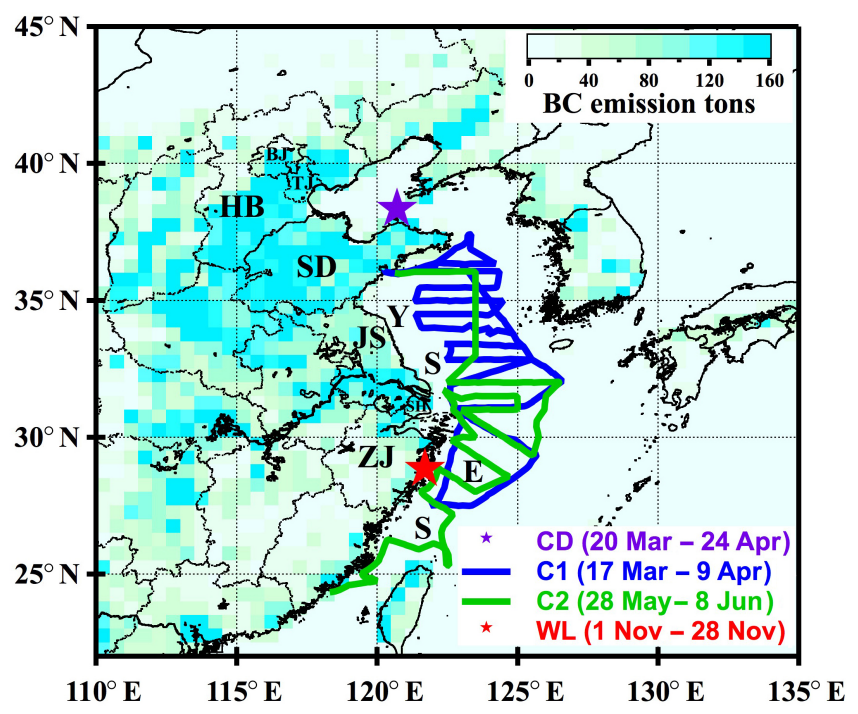

Figure 1. The coastal sites, cruise tracks, and their observation periods for the campaigns conducted in 2011. The purple star is the coastal site of Changdao Island (CD), and the red star is the coastal one of Wenling (WL). The blue line is the track of the first cruise $(\mathrm{C} 1)$ and the green line is the track of the second cruise. The yearly mean anthropogenic emission of $\mathrm{BC}$ is also colored on the map (MEIC, http://www.meicmodel.org). Abbreviations for provinces/cities: BJ - Beijing; TJ - Tianjin; HB - Hebei; SD Shandong; JS - Jiangsu; SH - Shanghai; ZJ - Zhejiang; YS - Yellow Sea; ES - East China Sea.

\section{Measurement and meteorology}

\subsection{Sampling sites and measurement}

To characterize the outflow of primary emissions from East China, a series of campaigns were conducted in the coastal regions in 2011 (Fig. 1). The first campaign was at Changdao Island (CD; $120.74^{\circ}$ E, $\left.37.92^{\circ} \mathrm{N}\right)$, Shandong Province, North China, from 20 March to 24 April, along with the first cruise observation (C1) conducted in the Yellow Sea (C1-YS) and East China Sea (C1-ES), from 17 March to 9 April. The second was another cruise observation in the East China Sea (C2-ES) from 28 May to 8 June. The third was at the Wenling coastal site (WL; $\left.121.74^{\circ} \mathrm{E}, 28.43^{\circ} \mathrm{N}\right)$, Zhejiang Province, South China, from 1 to 28 November.

As shown in Fig. 1, Changdao Island (CD) is located off the eastern coast in North China. To its west and south are the cities of Beijing and Tianjin and the provinces of Hebei and Shandong, which have the largest emissions of $\mathrm{BC}$ in North China. Wenling (WL) is located at the eastern coast in South China. Considerable BC is emitted in the boundary areas of the Yangtze River Delta of Zhejiang, Jiangsu, and Shanghai, leading to impacts on Wenling when the northwesterly wind is predominant. A more detailed description of these two sites can be seen in previous studies (Guo et al., 2015; Yuan et al., 2013; Hu et al., 2013; Peng et al., 2016a). 
To the east of Changdao Island and Wenling are the Yellow Sea and East China Sea, which are marginal seas surrounded by China, North and South Korea, and Japan.

A suite of online instrument was deployed for gaseous and particulate pollutants measurements during the campaigns. For the primary emission and $\mathrm{BC}$ aging are the focuses, both $\mathrm{BC}$ and $\mathrm{CO}$ hourly averaged data are used in this work. $\mathrm{BC}$ mass concentration was continually measured by an Aethalometer (AE-31, Magee Scientific, USA) with an integration time of $5 \mathrm{~min}$. Aethalometers have been widely used for BC measurement and have shown excellent agreement with other techniques, such as thermal and photo-acoustic methods (Zhou et al., 2009; Girach et al., 2014; Nair et al., 2007; Hitzenberger et al., 2006). The uncertainty for BC mass concentration was estimated to be $10 \%$. CO mixing ratio was measured by a trace level enhanced $\mathrm{CO}$ analyzer (48i-TLE, Thermo Scientific, USA) with an integration time of 1 min. The $\mathrm{CO}$ analyzer was calibrated using a CO standard every week, and zero-checks were performed every day. The overall uncertainty for $\mathrm{CO}$ measurement was estimated to be less than $10 \%$. For the cruise observation, the data with simultaneously sharp increase in concentrations of BC and $\mathrm{CO}$ were screened and excluded from the dataset to avoid contamination by ship emissions.

\subsection{Meteorological conditions}

Figure $2 \mathrm{a}-\mathrm{d}$ show the mean synoptic wind flow patterns at $925 \mathrm{hPa}$ for the Changdao Island (CD), the first cruise (C1), the second cruise (C2), and Wenling (WL) campaign periods, respectively, as obtained from NCEP/NCAR reanalysis (http://www.esrl.noaa.gov/psd). These flow patterns reveal the typical impact of the East Asian monsoon over the eastern coast of China, which includes the winter and summer monsoon. Generally, the winter monsoon lasts from November to the following April with prevailing northwesterly wind, while the summer monsoon continues from May to October with predominantly southwesterly wind.

As can be seen in Fig. 2a, b, and d, Changdao Island, the Yellow Sea and East China Sea, and Wenling were influenced by the winter monsoon during the $\mathrm{CD}, \mathrm{C} 1$, and WL campaigns, respectively, whereas the East China Sea (Fig. 2c) was impacted by the summer monsoon during the $\mathrm{C} 2$ campaign. Though $\mathrm{CD}$ and $\mathrm{C} 1$ were in the same period, $\mathrm{C} 1$ ended 2 weeks earlier than CD, as indicated in Fig. 1. Consequently, though there were differences in wind speed, their flow patterns were mostly consistent. In addition, the wind flow pattern during C1 was also comparable with that during WL. However, there was a small discrepancy in wind direction, which implies that they were in opposite phases of the winter monsoon - that is, the period during $\mathrm{C} 1$ was at the end of the winter monsoon, which would become weaker and transition to the summer monsoon, and the period during WL was at the start of the winter monsoon. The wind flow patterns during the first and second cruise were almost opposite in direction
(Fig. 2b and c), which suggests that the air mass during the first cruise mainly flowed from North China to the Yellow Sea and then to the East China Sea, whereas during the second cruise the air mass direction was from South China to the East China Sea.

\section{Results}

\subsection{Variability in $\mathrm{BC}$ and $\mathrm{CO}$ concentration}

The average $\mathrm{BC}$ mass concentrations were 2.43, 1.09, 0.94, 0.77 , and $2.73 \mu \mathrm{g} \mathrm{m}^{-3}$ for CD, C1-YS, C1-ES, C2-ES, and WL, respectively. Correspondingly, the average $\mathrm{CO}$ mixing ratios were $0.55,0.31,0.36,0.27$, and $0.48 \mathrm{ppm}$. The average concentrations between coastal sites were similar, as were the concentrations between different sea areas. It is clear that the pollutants' concentrations at coastal sites are higher than those in the marine atmosphere, but BC and $\mathrm{CO}$ in the Yellow Sea and East China Sea still had considerable loadings, implying severe anthropogenic pollution from the continent.

$\mathrm{BC}$ and $\mathrm{CO}$ at Changdao Island had concentration ranges of $0.3-8.5 \mathrm{\mu g} \mathrm{m}^{-3}$ and 0.1-2.9 ppm (Fig. 3a), while BC at Wenling had a wider range of $0.1-13.7 \mu \mathrm{g} \mathrm{m}^{-3}$ and $\mathrm{CO}$ had a narrower range of $0.1-1.6 \mathrm{ppm}$ (Fig. 3b). This difference between coastal sites is associated with the distinct pollutant emissions between North and South China, which will be discussed further in the Sect. 3.2. At the same time, except for the pollution episode on 8 April during C1-YS, the concentrations for $\mathrm{BC}$ and $\mathrm{CO}$ over the sea were less than $4 \mu \mathrm{g} \mathrm{m}^{-3}$ and $1 \mathrm{ppm}$, respectively. The different concentration ranges between coastal sites and sea areas are related to the distance to the continental source. The episode in the Yellow Sea on 8 April also occurred at Changdao Island from 7 to 8 April (shown in the dashed rectangle in Fig. 3a and b), indicating a regional pollution episode over these areas. The peak concentrations for $\mathrm{BC}(\mathrm{CO})$ between the island and the Yellow Sea were almost the same, but the peak concentration for Changdao Island (7 April, 18:00 LT) appeared 14 h earlier than that for the Yellow Sea (8 April, 08:00 LT), which could be considered to be the transport time between the island and the Yellow Sea during the regional pollution. In order to verify this, the forward and backward trajectories were run starting at Changdao Island and in the Yellow Sea, respectively (http://www.ready.noaa.gov). The green line (Fig. S1 in the Supplement) is the $24 \mathrm{~h}$ forward trajectory starting at BC peak time for Changdao Island, and the green one (Fig. S2) is the $24 \mathrm{~h}$ backward trajectory starting at BC peak time for the Yellow Sea. Both lines show that the transport time from Changdao Island to the Yellow Sea was about $12 \mathrm{~h}$, which agrees with the peak time lag of $14 \mathrm{~h}$.

As illustrated in Fig. 3, the concentrations of $\mathrm{BC}$ and $\mathrm{CO}$ fluctuated consistently over the eastern coast of China, which indicates that they were from the same source. Apparently, the agreement during $\mathrm{CD}, \mathrm{C} 1$, and WL was much better than 

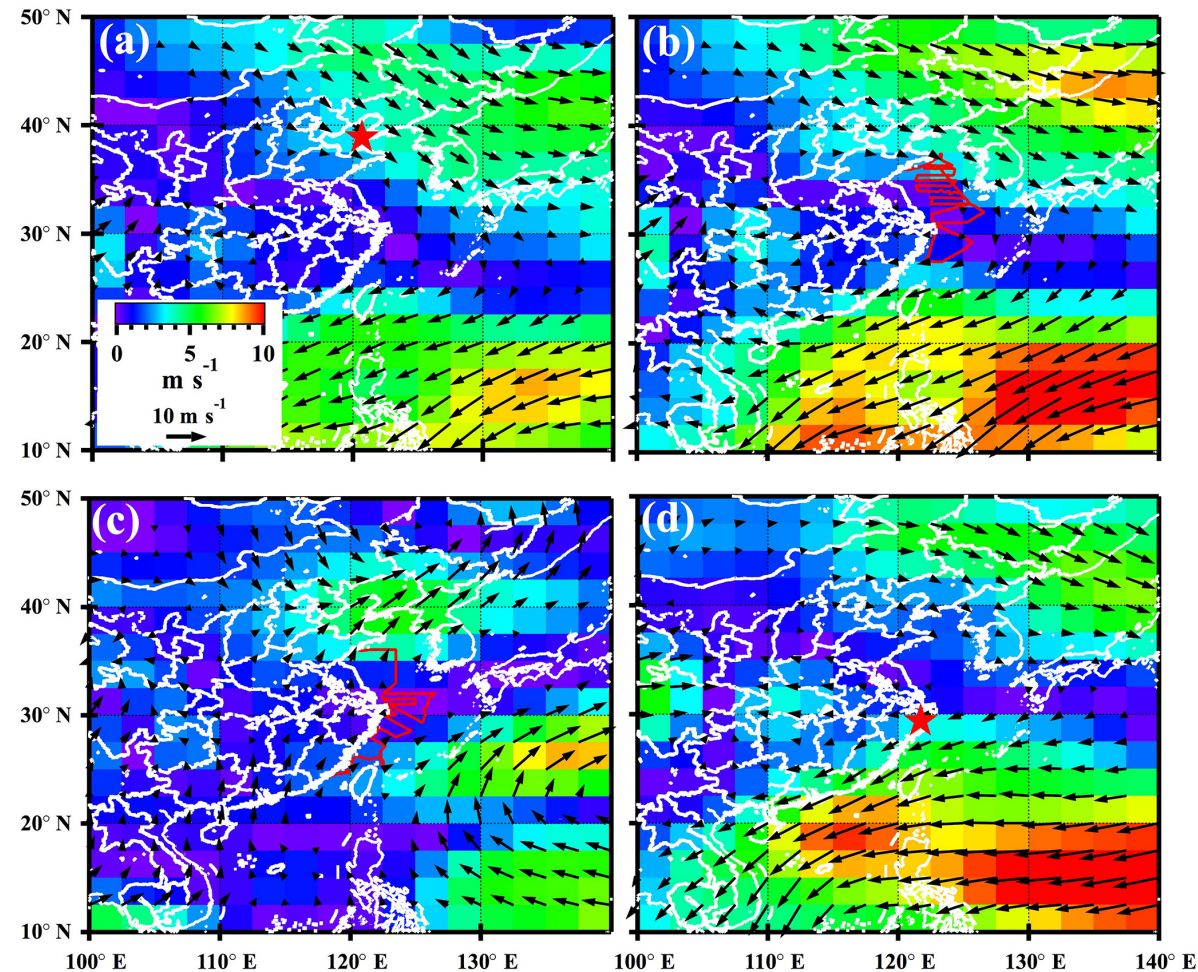

Figure 2. The synoptic wind flow patterns at $925 \mathrm{hPa}$ averaged over Changdao Island (a, red star, 20 March-24 April), the first cruise (b, red line, 17 March-9 April), the second cruise (c, red line, 28 May-8 June), and Wenling (d, red star, 1-28 November) campaign periods as shown in Fig. 1. The arrow length and color show the wind speed, while the arrowhead indicates the wind direction.

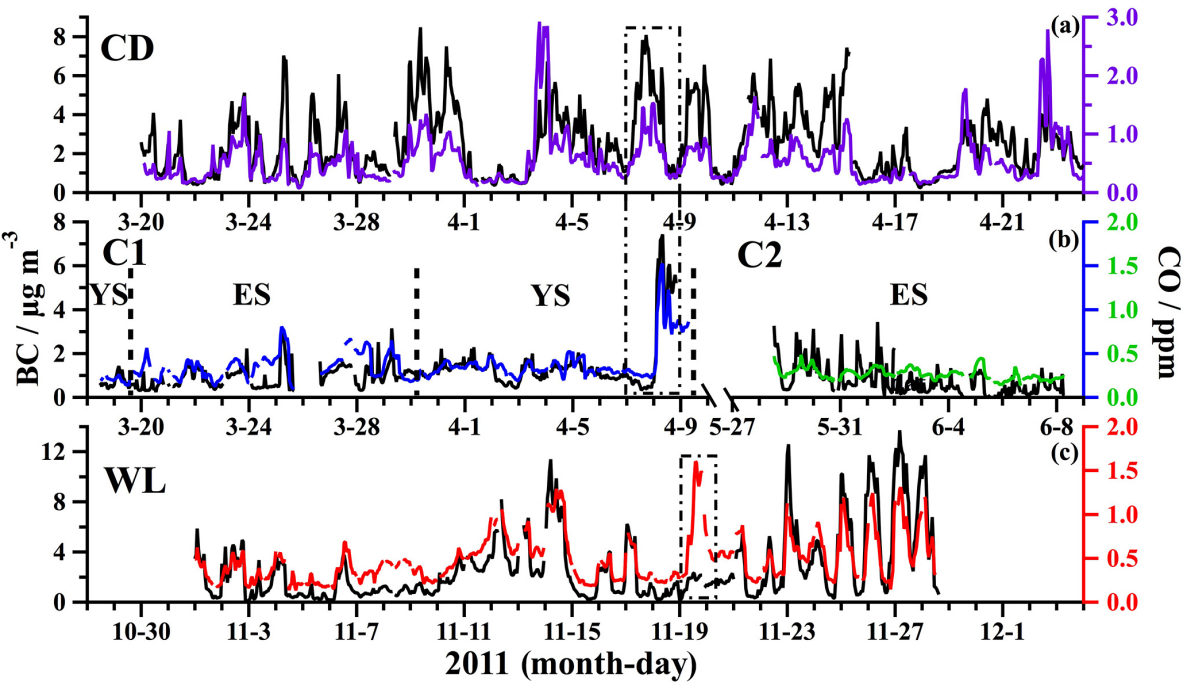

Figure 3. The time series of $\mathrm{BC}$ (the black lines) and $\mathrm{CO}$ (the lines coded by other colors) during the campaigns of Changdao Island (a), two cruises (b), and Wenling (c).

that during $\mathrm{C} 2$. In particular, $\mathrm{BC}$ and $\mathrm{CO}$ at the Wenling site exhibited the best agreement during the period from 22 to 28 November, suggesting significant impacts from primary emissions at the site. The reasons for the above variability will be discussed in the next two sections.
$4 \Delta \mathrm{BC} / \Delta \mathrm{CO}$ variability and comparison with other studies in East China

Figure 4 shows the relationship between $\mathrm{BC}$ and $\mathrm{CO}$ for all campaigns. The data points for the Yellow Sea in the first 

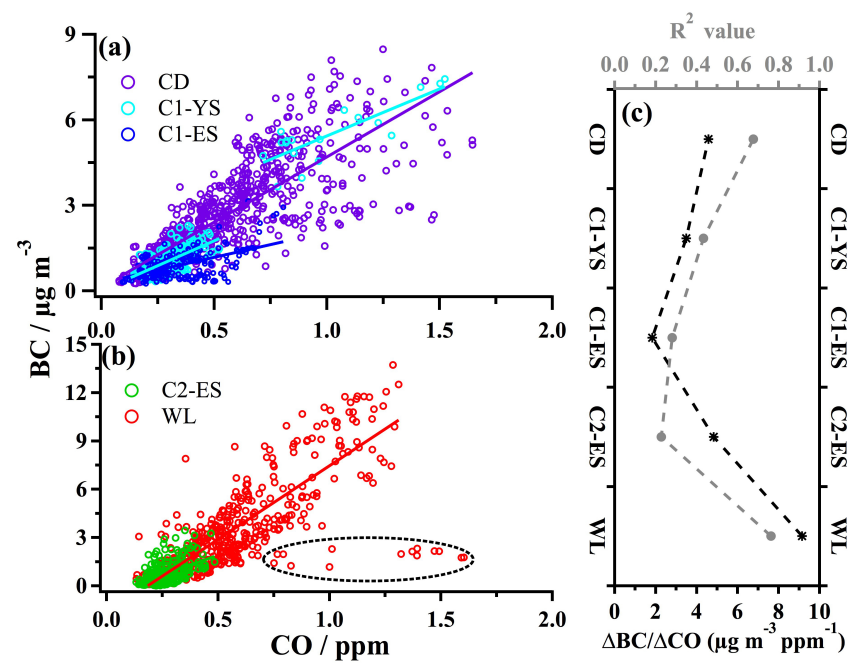

Figure 4. Scatter plots of $\mathrm{BC}$ vs. $\mathrm{CO}(\mathbf{a}, \mathbf{b})$ and their regression slopes and correlation coefficients (c).

cruise (C1-YS) all overlap with those for Changdao Island (Fig. 4a), which is similar to the case between the East China Sea in the second cruise (C2-ES) and Wenling (Fig. 4b). This indicates that both C1-YS and CD (or C2-ES and WL) were influenced by the same air mass. However, the data points within the dashed oval in Fig. 4b are separate from most of the data for the Wenling campaign. These data points correspond to those on 19 November (dashed rectangle in Fig. 2c), when the $\mathrm{CO}$ mixing ratio was highest during the campaign and $\mathrm{BC}$ mass concentration was relatively low. During the campaign, heavy precipitation was recorded at midnight on 18 November. This is in agreement with the removal mechanism that the precipitation can much more easily remove aged BC without affecting CO (Hertel et al., 1995; Girach et al., 2014). Therefore, the data impacted by the precipitation are excluded in regressing the $\triangle \mathrm{BC} / \triangle \mathrm{CO}$ slope for Wenling.

The $\triangle \mathrm{BC} / \triangle \mathrm{CO}$ values at coastal sites are compared with those in other studies in East China (Fig. 5a) to find possible reasons for the distinct ratios among the continental sites. The studies which simultaneously measured $\mathrm{BC}$ and $\mathrm{CO}$ are centered in megacities such as Beijing, Shanghai, and Guangzhou (Han et al., 2009; Zhou et al., 2009; Andreae et al., 2008). However there are still very few studies in the North China Plain, where the largest amounts of BC are emitted, and $\triangle \mathrm{BC} / \triangle \mathrm{CO}$ values are not given in some publications although $\mathrm{BC}$ and $\mathrm{CO}$ were measured (Sun et al., 2013). Since the continental sites are close to source regions, it is speculated that the $\triangle \mathrm{BC} / \triangle \mathrm{CO}$ values are determined more by primary emission than by atmospheric processing.

The strong and positive correlation between $\mathrm{BC}$ and $\mathrm{CO}$ is attributed to common sources such as vehicular emissions (Badarinath et al., 2007). In the vehicular emissions, CO is primarily emitted from gasoline vehicles, while $\mathrm{BC}$ emis- sions are dominated by diesel vehicles (Han et al., 2009). In a previous study (Zhou et al., 2009), the difference in $\Delta B C / \triangle C O$ values between Beijing and Shanghai was attributed to the higher percentage of diesel vehicles in Shanghai. As shown in Fig. 5a, the $\Delta \mathrm{BC} / \Delta \mathrm{CO}$ values in Beijing and Changdao Island in North China are less than those in Nanjing, Shanghai, Wenling, and Guangzhou in South China, suggesting disparate fuel structures in North and South China. To prove this, the $\Delta \mathrm{BC} / \Delta \mathrm{CO}$ values at different sites were compared with the ratios of diesel consumption to gasoline consumption in each province/city (China Energy Statistical Yearbook, 2013); these show considerable correlation $\left(R^{2}=0.63\right.$, Fig. $\left.5 \mathrm{~b}\right)$, confirming that $\mathrm{BC}$ and $\mathrm{CO}$ are mainly from vehicular emissions. A consumption ratio less than 1 in Beijing indicates that gasoline is dominant in North China, while a ratio more than 1 in Nanjing, Shanghai, Wenling, and Guangzhou implies that diesel is dominant in South China. However, the data point for Changdao Island in Shandong Province is excluded from the regression line for other sites. The reason for this is that Changdao Island is a rural site with little local vehicle emission, and it was influenced by Beijing and its surrounding regions during the Asian winter monsoon, when the predominant wind was northwesterly (Fig. 2a). The $\triangle \mathrm{BC} / \Delta \mathrm{CO}$ value at Changdao Island was thus less than that in Beijing.

Although the $\triangle \mathrm{BC} / \triangle \mathrm{CO}$ values and consumption ratios have a good correlation $\left(R^{2}=0.63\right)$, the consumption ratios cannot fully explain the variability in $\Delta \mathrm{BC} / \Delta \mathrm{CO}$ values. In one aspect, vehicular consumption of diesel and gasoline is only a part of the total fuel consumption. In another aspect, $\mathrm{BC}$ and $\mathrm{CO}$ are controlled not only by emission from the local province/city but also by emission transported from other areas on a regional scale. Moreover, other sources such as biomass burning can also contribute to $\mathrm{BC}$ and $\mathrm{CO}$ and change the $\Delta \mathrm{BC} / \triangle \mathrm{CO}$ value.

\section{$5 \quad$ BC aging during transport}

The $\triangle \mathrm{BC} / \triangle \mathrm{CO}$ variability can result from the spatial variation of $\mathrm{BC}$ and $\mathrm{CO}$ source/sink strength (Badarinath et al., 2007). Since most of BC emission sources are centered in East China (Fig. 1), the $\Delta \mathrm{BC} / \Delta \mathrm{CO}$ variability depends on emission sources before $\mathrm{BC}$ leaves the continent, as indicated by the comparison in Sect. 3.2, which elucidates the disparate fuel structures between North and South China. When BC is transported to the marine boundary layer, the variability in the $\triangle \mathrm{BC} / \triangle \mathrm{CO}$ ratio is dominantly associated with $\mathrm{BC}$ aging and removal, given the insignificant anthropogenic sources in the marine boundary layer. Therefore, the $\Delta \mathrm{BC} / \Delta \mathrm{CO}$ values between the continental and marine atmospheres may be an ideal comparison to reflect the aging extent of $\mathrm{BC}$.

Owing to the aging and removal of $\mathrm{BC}$ and the longer atmospheric lifetime of $\mathrm{CO}$, the slopes, i.e., the ratios of $\triangle \mathrm{BC}$ to $\triangle \mathrm{CO}$ and correlation coefficients will decrease together 

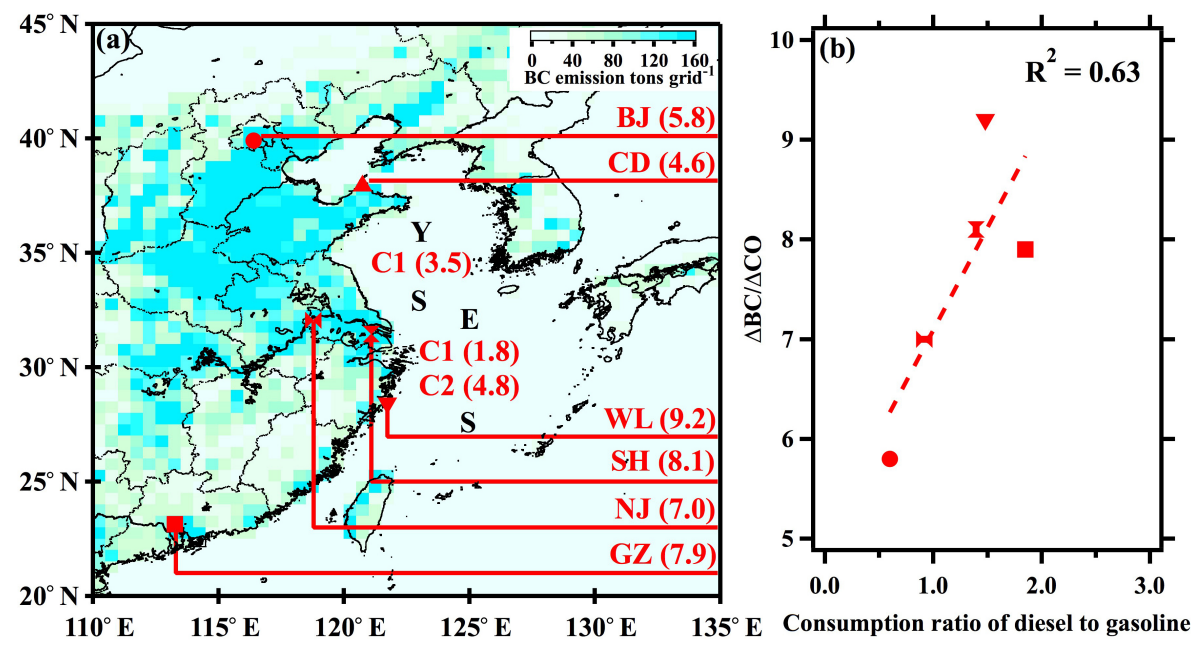

Figure 5. The $\triangle \mathrm{BC} / \triangle \mathrm{CO}$ ratios in this study and other studies in East China (a) and their function of the ratios of diesel consumption to gasoline consumption in each province/city (b).

from upwind to downwind areas. The $\triangle \mathrm{BC} / \Delta \mathrm{CO}$ values for Changdao, C1-YS (excluding the episode data), and C1-ES are $4.58,3.49$, and $1.84 \mathrm{\mu g} \mathrm{m}^{-3} \mathrm{ppm}^{-1}$, respectively, showing a descending trend from north to south over the eastern coast of China (Fig. 4c). This was consistent with the predominant northwestern wind during the winter monsoon (Fig. 2a and b). Meanwhile, the correlation coefficients reduce from 0.68 to 0.28 (Fig. 4c). Therefore the slopes and correlation coefficients determined from the linear regression are possible indicators of the aging and deposition of $\mathrm{BC}$ during transport. This can be evidenced by the pollution episode in the Yellow Sea during the first cruise, where BC and CO have a slope of $3.30 \mu \mathrm{g} \mathrm{m}^{-3} \mathrm{ppm}^{-1}$ and a correlation coefficient of 0.68 . Though the slope is a little smaller than that at Changdao Island $\left(4.58 \mu \mathrm{g} \mathrm{m}^{-3} \mathrm{ppm}^{-1}\right)$, the correlation coefficient is the same.

Under the influence of the summer monsoon (Fig. 2c), the East China Sea is located in the downwind of Wenling. The $\triangle \mathrm{BC} / \triangle \mathrm{CO}$ values for Changdao Island $\left(4.58 \mu \mathrm{g} \mathrm{m}^{-3} \mathrm{ppm}^{-1}\right)$ and C2-ES $\left(4.84 \mu \mathrm{g} \mathrm{m}^{-3} \mathrm{ppm}^{-1}\right)$ are similar, but the $\Delta \mathrm{BC} / \triangle \mathrm{CO}$ value for Wenling $\left(9.15 \mu \mathrm{g} \mathrm{m}^{-3} \mathrm{ppm}^{-1}\right)$ is 2 times more than those at $\mathrm{CD}$ and C2-ES, which means that the source region for C2-ES was in South China rather than in North China. Thus, the campaigns of C2-ES and WL can be considered as a transport process, though these two campaigns are not simultaneously conducted. The $\triangle \mathrm{BC} / \Delta \mathrm{CO}$ values and correlation coefficient for WL and C2-ES during the summer monsoon also showed a descending trend, as was the case for those for CD, C1-YS, and C1-ES during the winter monsoon (Fig. 4c). Therefore, the decreasing slopes and correlation coefficients from source to receptor areas indicate more aging and easier removal of $\mathrm{BC}$ after outflow from the source regions. It is well known that, at a microscopic level, $\mathrm{BC}$ aging is generally indicated by the coating thickness, and the coating thick- ness is associated with the mixing state and morphological variation (Khalizov et al., 2009b; Pagels et al., 2009), which ultimately enhance BC aging. It is shown here that, at the macroscopic level, $\mathrm{BC}$ aging and subsequent removal result in variation of $\triangle B C / \triangle C O$ values and correlation coefficients in the relationship between $\mathrm{BC}$ and $\mathrm{CO}$, which deepens the comprehensive understanding on $\mathrm{BC}$ aging.

The BC average concentration for C1-ES $\left(0.94 \mu \mathrm{g} \mathrm{m}^{-3}\right)$ during the winter monsoon was only a little higher than that for C2-ES $\left(0.77 \mu \mathrm{g} \mathrm{m}^{-3}\right)$ during the summer monsoon. However, the $\triangle \mathrm{BC} / \triangle \mathrm{CO}$ value in $\mathrm{C} 1$-ES was 0.4 times less than that in Changdao Island, and the ratio in C2-ES was nearly 0.55 times less than that in Wenling, indicating more aging of $\mathrm{BC}$ in the East China Sea during the winter monsoon. Due to the greater extent of aging, BC during the winter monsoon can be more hygroscopic and resulted in a more significant radiative effect (Moffet and Prather, 2009; Bond and Bergstrom, 2006).

\section{Conclusions}

Atmospheric campaigns including two island/coastal sites and two cruises were conducted in 2011 to characterize the outflow of primary emission over the eastern coast of China. Due to a large amount of continental pollutant emissions, there were considerable loadings of $\mathrm{BC}$ and $\mathrm{CO}$ in the coast and sea areas in East China under the influence of the Asian monsoon. The slopes, i.e., the ratios of $\triangle \mathrm{BC}$ to $\triangle \mathrm{CO}$ from the relationship between $\mathrm{BC}$ and $\mathrm{CO}$, were regressed to deduce information about $\mathrm{BC}$ source and aging during transport. The $\Delta \mathrm{BC} / \Delta \mathrm{CO}$ values in North China were smaller than those in South China, which revealed the disparate fuel structures between North and South China. The $\Delta \mathrm{BC} / \Delta \mathrm{CO}$ values were well associated with the ra- 
tios of diesel consumption to gasoline consumption in each province/city, which confirmed that $\mathrm{BC}$ and $\mathrm{CO}$ were primarily from vehicular emissions. The consumption ratios imply that gasoline was dominant in North China while diesel was dominant in South China.

The comparison of $\Delta \mathrm{BC} / \Delta \mathrm{CO}$ values between the coastal site and the sea area reflected the aging and deposition of BC. During the simultaneous measurements of Changdao Island and the first cruise, the $\triangle \mathrm{BC} / \triangle \mathrm{CO}$ value and the correlation coefficient decreased with the distance from the source under the influence of the winter monsoon. The $\Delta \mathrm{BC} / \Delta \mathrm{CO}$ value and the correlation coefficient also showed a decreasing trend from Wenling to the East China Sea. Therefore, the $\Delta \mathrm{BC} / \Delta \mathrm{CO}$ ratio and the correlation coefficient are possible indicators for $\mathrm{BC}$ aging and removal after outflow from the source regions, which deepens the comprehensive understanding of $\mathrm{BC}$ aging at the macroscopic level.

Data availability. The data presented in this article are available from the authors upon request (minhu@ pku.edu.cn).

\section{The Supplement related to this article is available online at https://doi.org/10.5194/acp-17-10395-2017- supplement.}

Competing interests. The authors declare that they have no conflict of interest.

Special issue statement. This article is part of the special issue "Regional transport and transformation of air pollution in eastern China". It is not associated with a conference.

Acknowledgements. This work was supported by the National Basic Research Program of China (973 Program) (2013CB228503), National Natural Science Foundation of China (91544214, 41421064, 21677002), China Ministry of Environmental Protection's Special Funds for Scientific Research on Public Welfare (201009002), and National Key Research and Development Program of China (2016YFC0202003). We thank the CAPTAIN team from Peking University, Peking University Shenzhen Graduate School, and Zhejiang Province Environmental Monitoring Center for their help and support for this research.

Edited by: Renyi Zhang

Reviewed by: two anonymous referees

\section{References}

Andreae, M. O., Schmid, O., Yang, H., Chand, D., Yu, J. Z., Zeng, L. M., and Zhang, Y. H.: Optical properties and chemical composition of the atmospheric aerosol in urban Guangzhou, China, Atmos. Environ., 42, 6335-6350, https://doi.org/10.1016/j.atmosenv.2008.01.030, 2008.

Badarinath, K. V. S., Latha, K. M., Chand, T. R. K., Reddy, R. R., Gopal, K. R., Reddy, L. S. S., Narasimhulu, K., and Kumar, K. R.: Black carbon aerosols and gaseous pollutants in an urban area in North India during a fog period, Atmos. Res., 85, 209-216, https://doi.org/10.1016/j.atmosres.2006.12.007, 2007.

Bond, T., Doherty, S., Fahey, D., Forster, P., Berntsen, T., DeAngelo, B., Flanner, M., Ghan, S., Kärcher, B., and Koch, D.: Bounding the role of black carbon in the climate system: a scientific assessment, J. Geophys. Res.-Atmos., 118, 5380-5552, https://doi.org/10.1002/jgrd.50171, 2013.

Bond, T. C. and Bergstrom, R. W.: Light absorption by carbonaceous particles: an investigative review, Aerosol Sci. Tech., 40, 27-67, https://doi.org/10.1080/02786820500421521, 2006.

Bond, T. C., Streets, D. G., Yarber, K. F., Nelson, S. M., Woo, J.-H., and Klimont, Z.: A technology-based global inventory of black and organic carbon emissions from combustion, J. Geophys. Res.-Atmos., 109, D14203, https://doi.org/10.1029/2003JD003697, 2004.

Bond, T. C., Habib, G., and Bergstrom, R. W.: Limitations in the enhancement of visible light absorption due to mixing state, J. Geophys. Res.-Atmos., 111, D20211, https://doi.org/10.1029/2006JD007315, 2006.

De Gouw, J. and Jimenez, J. L.: Organic aerosols in the Earth's atmosphere, Environ. Sci. Technol., 43, 7614-7618, https://doi.org/10.1021/es9006004, 2009.

de Gouw, J. A., Middlebrook, A. M., Warneke, C., Goldan, P. D., Kuster, W. C., Roberts, J. M., Fehsenfeld, F. C., Worsnop, D. R., Canagaratna, M. R., Pszenny, A. A. P., Keene, W. C., Marchewka, M., Bertman, S. B., and Bates, T. S.: Budget of organic carbon in a polluted atmosphere: results from the New England Air Quality Study in 2002, J. Geophys. Res.-Atmos., 110, D16305, https://doi.org/10.1029/2004JD005623, 2005.

Feng, J. L., Guo, Z. G., Chan, C. K., and Fang, M.: Properties of organic matter in $\mathrm{PM}_{2.5}$ at Changdao Island, China - a rural site in the transport path of the Asian continental outflow, Atmos. Environ., 41, 1924-1935, https://doi.org/10.1016/j.atmosenv.2006.10.064, 2007.

Girach, I. A., Nair, V. S., Babu, S. S., and Nair, P. R.: Black carbon and carbon monoxide over Bay of Bengal during W_ICARB: source characteristics, Atmos. Environ., 94, 508517, https://doi.org/10.1016/j.atmosenv.2014.05.054, 2014.

Guo, Q., Hu, M., Guo, S., Wu, Z., Hu, W., Peng, J., Hu, W., Wu, Y., Yuan, B., Zhang, Q., and Song, Y.: The identification of source regions of black carbon at a receptor site off the eastern coast of China, Atmos. Environ., 100, 78-84, https://doi.org/10.1016/j.atmosenv.2014.10.053, 2015.

Guo, S., Hu, M., Lin, Y., Gomez-Hernandez, M., Zamora, M. L., Peng, J. F., Collins, D. R., and Zhang, R. Y.: OH-initiated oxidation of m-xylene on black carbon aging, Environ. Sci. Technol., 50, 8605-8612, 2016.

Han, S., Kondo, Y., Oshima, N., Takegawa, N., Miyazaki, Y., Hu, M., Lin, P., Deng, Z., Zhao, Y., Sugimoto, N., and Wu, Y.: Temporal variations of elemental car- 
bon in Beijing, J. Geophys. Res.-Atmos., 114, D23202, https://doi.org/10.1029/2009jd012027, 2009.

He, C., Liou, K. N., Takano, Y., Zhang, R., Zamora, M. L., Yang, P., Li, Q., and Leung, L. R.: Variation of the radiative properties during black carbon aging: theoretical and experimental intercomparison, Atmos. Chem. Phys., 15, 11967-11980, https://doi.org/10.5194/acp-15-11967-2015, 2015.

He, C. L., Li, Q. B., Liou, K. N., Qi, L., Tao, S., and Schwarz, J. P.: Microphysics-based black carbon aging in a global CTM: constraints from HIPPO observations and implications for global black carbon budget, Atmos. Chem. Phys., 16, 3077-3098, https://doi.org/10.5194/acp-16-3077-2016, 2016.

Hertel, O., Christensen, J., Runge, E. H., Asman, W. A. H., Berkowicz, R., Hovmand, M. F., and Hov, O.: Development and testing of a new variable scale air-pollution model - Acdep, Atmos. Environ., 29, 1267-1290, https://doi.org/10.1016/13522310(95)00067-9, 1995.

Hitzenberger, R., Petzold, A., Bauer, H., Ctyroky, P., Pouresmaeil, P., Laskus, L., and Puxbaum, H.: Intercomparison of thermal and optical measurement methods for elemental carbon and black carbon at an urban location, Environ. Sci. Technol., 40, 6377-6383, 2006.

Hu, W. W., Hu, M., Yuan, B., Jimenez, J. L., Tang, Q., Peng, J. F., Hu, W., Shao, M., Wang, M., Zeng, L. M., Wu, Y. S., Gong, Z. H., Huang, X. F., and He, L. Y.: Insights on organic aerosol aging and the influence of coal combustion at a regional receptor site of central eastern China, Atmos. Chem. Phys., 13, 10095-10112, https://doi.org/10.5194/acp-13-10095-2013, 2013.

Huang, Y., Wu, S., Dubey, M. K., and French, N. H. F.: Impact of aging mechanism on model simulated carbonaceous aerosols, Atmos. Chem. Phys., 13, 6329-6343, https://doi.org/10.5194/acp13-6329-2013, 2013.

Khalizov, A. F., Xue, H., Wang, L., Zheng, J., and Zhang, R.: Enhanced light absorption and scattering by carbon soot aerosol internally mixed with sulfuric acid, J. Phys. Chem. A, 113, 10661074, https://doi.org/10.1021/jp807531n, 2009a.

Khalizov, A. F., Zhang, R., Zhang, D., Xue, H., Pagels, J., and McMurry, P. H.: Formation of highly hygroscopic soot aerosols upon internal mixing with sulfuric acid vapor, J. Geophys. Res.Atmos., 114, D05208, https://doi.org/10.1029/2008JD010595, $2009 b$.

Lee, Y. C., Lam, Y. F., Kuhlmann, G., Wenig, M. O., Chan, K. L., Hartl, A., and Ning, Z.: An integrated approach to identify the biomass burning sources contributing to black carbon episodes in Hong Kong, Atmos. Environ., 80, 478-487, https://doi.org/10.1016/j.atmosenv.2013.08.030, 2013.

Li, Z. Q., Lau, W. K. M., Ramanathan, V., Wu, G., Ding, Y., Manoj, M. G., Liu, J., Qian, Y., Li, J., Zhou, T., Fan, J., Rosenfeld, D., Ming, Y., Wang, Y., Huang, J., Wang, B., Xu, X., Lee, S. S., Cribb, M., Zhang, F., Yang, X., Zhao, C., Takemura, T., Wang, K., Xia, X., Yin, Y., Zhang, H., Guo, J., Zhai, P. M., Sugimoto, N., Babu, S. S., and Brasseur, G. P.: Aerosol and monsoon climate interactions over Asia, Rev. Geophys., 54, 866-929, 2016.

McMeeking, G. R., Hamburger, T., Liu, D., Flynn, M., Morgan, W. T., Northway, M., Highwood, E. J., Krejci, R., Allan, J. D., Minikin, A., and Coe, H.: Black carbon measurements in the boundary layer over western and northern Europe, At- mos. Chem. Phys., 10, 9393-9414, https://doi.org/10.5194/acp10-9393-2010, 2010.

Moffet, R. C. and Prather, K. A.: In-situ measurements of the mixing state and optical properties of soot with implications for radiative forcing estimates, P. Natl. Acad. Sci. USA, 106, 1187211877, https://doi.org/10.1073/pnas.0900040106, 2009.

Nair, V. S., Moorthy, K. K., Alappattu, D. P., Kunhikrishnan, P. K., George, S., Nair, P. R., Babu, S. S., Abish, B., Satheesh, S. K., Tripathi, S. N., Niranjan, K., Madhavan, B. L., Srikant, V., Dutt, C. B. S., Badarinath, K. V. S., and Reddy, R. R.: Wintertime aerosol characteristics over the Indo-Gangetic Plain (IGP): impacts of local boundary layer processes and long-range transport, J. Geophys. Res.-Atmos., 112, D13205, https://doi.org/10.1029/2006JD008099, 2007.

Pagels, J., Khalizov, A. F., McMurry, P. H., and Zhang, R. Y.: Processing of soot by controlled sulphuric acid and water condensation - mass and mobility relationship, Aerosol Sci. Tech., 43, 629-640, 2009.

Pan, X. L., Kanaya, Y., Wang, Z. F., Liu, Y., Pochanart, P., Akimoto, H., Sun, Y. L., Dong, H. B., Li, J., Irie, H., and Takigawa, M.: Correlation of black carbon aerosol and carbon monoxide in the high-altitude environment of Mt. Huang in Eastern China, Atmos. Chem. Phys., 11, 9735-9747, https://doi.org/10.5194/acp-11-9735-2011, 2011.

Peltier, R. E., Hecobian, A. H., Weber, R. J., Stohl, A., Atlas, E. L., Riemer, D. D., Blake, D. R., Apel, E., Campos, T., and Karl, T.: Investigating the sources and atmospheric processing of fine particles from Asia and the Northwestern United States measured during INTEX B, Atmos. Chem. Phys., 8, 1835-1853, https://doi.org/10.5194/acp-8-1835-2008, 2008.

Peng, J. F., Hu, M., Gong, Z. H., Tian, X. D., Wang, M., Zheng, J., Guo, Q. F., Cao, W., Lv, W., Hu, W. W., Wu, Z. J., and Guo, S.: Evolution of secondary inorganic and organic aerosols during transport: a case study at a regional receptor site, Environ. Pollut., 218, 794-803, 2016a.

Peng, J. F., Hu, M., Guo, S., Du, Z. F., Zheng, J., Shang, D. J., Zamora, M. L., Zeng, L. M., Shao, M., Wu, Y. S., Zheng, J., Wang, Y., Glen, C. R., Collins, D. R., Molina, M. J., and Zhang, R. Y.: Markedly enhanced absorption and direct radiative forcing of black carbon under polluted urban environments, P. Natl. Acad. Sci. USA, 113, 4266-4271, 2016b.

Schnaiter, M., Linke, C., Mohler, O., Naumann, K. H., Saathoff, H., Wagner, R., Schurath, U., and Wehner, B.: Absorption amplification of black carbon internally mixed with secondary organic aerosol, J. Geophys. Res.-Atmos., 110, D19204, https://doi.org/10.1029/2005JD006046, 2005.

Spackman, J. R., Schwarz, J. P., Gao, R. S., Watts, L. A., Thomson, D. S., Fahey, D. W., Holloway, J. S., de Gouw, J. A., Trainer, M., and Ryerson, T. B.: Empirical correlations between black carbon aerosol and carbon monoxide in the lower and middle troposphere, Geophys. Res. Lett., 35, L19816, https://doi.org/10.1029/2008gl035237, 2008.

Sun, Y. W., Zhou, X. H., Wai, K. M., Yuan, Q., Xu, Z., Zhou, S. Z., Qi, Q., and Wang, W. X.: Simultaneous measurement of particulate and gaseous pollutants in an urban city in North China Plain during the heating period: implication of source contribution, Atmos. Res., 134, 24-34, https://doi.org/10.1016/j.atmosres.2013.07.011, 2013. 
Wang, Q. Y., Liu, S. X., Zhou, Y. Q., Cao, J. J., Han, Y. M., Ni, H. Y., Zhang, N. N., and Huang, R. J.: Characteristics of black carbon aerosol during the chinese lunar year and weekdays in Xi'an, China, Atmosphere-Basel, 6, 195-208, https://doi.org/10.3390/atmos6020195, 2015.

Wang, Y., Khalizov, A., Levy, M., and Zhang, R. Y.: New directions: light absorbing aerosols and their atmospheric impacts, Atmos. Environ., 81, 713-715, 2013.

Wang, Y., Ma, P. L., Jiang, J. H., Su, H., and Rasch, P. J.: Toward reconciling the influence of atmospheric aerosols and greenhouse gases on light precipitation changes in Eastern China, J. Geophys. Res.-Atmos., 121, 5878-5887, 2016.

Wang, Y. X., Wang, X., Kondo, Y., Kajino, M., Munger, J. W., and Hao, J. M.: Black carbon and its correlation with trace gases at a rural site in Beijing: top-down constraints from ambient measurements on bottom-up emissions, J. Geophys. Res.-Atmos., 116, D24304, https://doi.org/10.1029/2011jd016575, 2011.
Yuan, B., Hu, W. W., Shao, M., Wang, M., Chen, W. T., Lu, S. H., Zeng, L. M., and Hu, M.: VOC emissions, evolutions and contributions to SOA formation at a receptor site in eastern China, Atmos. Chem. Phys., 13, 8815-8832, https://doi.org/10.5194/acp13-8815-2013, 2013.

Zhang, R., Khalizov, A. F., Pagels, J., Zhang, D., Xue, H., and Mcmurry, P. H.: Variability in morphology, hygroscopicity, and optical properties of soot aerosols during atmospheric processing, P. Natl. Acad. Sci. USA, 105, 10291-10296, 2008.

Zhou, X., Gao, J., Wang, T., Wu, W., and Wang, W.: Measurement of black carbon aerosols near two Chinese megacities and the implications for improving emission inventories, Atmos. Environ., 43, 3918-3924, https://doi.org/10.1016/j.atmosenv.2009.04.062, 2009. 